\title{
TAPPS with Metaphorical Thinking Approach Assisted by Class Dojo to Improve Mathematical Literacy Skills
}

\author{
Wardono*, Scolastika Mariani, M. D Yanto \\ Department of Mathematics, Study Program Mathematics Education, Universitas Negeri Semarang, Semarang, Indonesia
}

Received October 8, 2020; Revised November 10, 2020; Accepted December 11, 2020

\section{Cite This Paper in the following Citation Styles}

(a): [1] Wardono, Scolastika Mariani, M. D Yanto , "TAPPS with Metaphorical Thinking Approach Assisted by Class Dojo to Improve Mathematical Literacy Skills," Universal Journal of Educational Research, Vol. 8, No. 12A, pp. 7511 7520, 2020. DOI: 10.13189/ujer.2020.082535.

(b): Wardono, Scolastika Mariani, M. D Yanto (2020). TAPPS with Metaphorical Thinking Approach Assisted by Class Dojo to Improve Mathematical Literacy Skills. Universal Journal of Educational Research, 8(12A), 7511 - 7520. DOI: 10.13189/ujer.2020.082535.

Copyright $\subseteq 2020$ by authors, all rights reserved. Authors agree that this article remains permanently open access under the terms of the Creative Commons Attribution License 4.0 International License

\begin{abstract}
The purpose of this research is to determine the learning quality of Think Aloud Pair Problem Solving learning model with metaphorical thinking approach assisted by Class Dojo to students' mathematical literacy skills. The research method used in this research is a quantitative method with a pretest-posttest control group design. The population in this research was VII graders students of SMP Negeri 9 Salatiga 2019/2020. The sample in this study was taken using simple random sampling technique with class VII B as the experimental class and class VII C as the control class. The results showed that the TAPPS learning model with metaphorical thinking approach assisted by Class Dojo has a quality to improve mathematical literacy skills. This is indicated by the average score of the learning device validation at the planning stage which is very good. The observation results of learning implementations and student responses were categorized as very good. In the evaluation stage, it shows that students after participating in the TAPPS learning model with metaphorical thinking approach assisted by Class Dojo can achieve more than the minimum completeness criteria (MCC) individually or classically, The proportion of classical completeness of student's mathematical literacy skill with the TAPPS learning model with metaphorical thinking approach assisted by Class Dojo is better than the proportion of classical completeness of student's mathematical literacy skill with the problem based learning model with scientific approach assisted by Google Classroom, and there is an increase in the average score of student's mathematical literacy skills taught by TAPPS learning model with metaphorical thinking
\end{abstract}

approach assisted by Class Dojo.

Keywords Mathematical Literacy, TAPPS, Metaphorical Thinking, Class Dojo

\section{Introduction}

Every level of society has the right to receive the best and highest possible education. Humans can develop through education, forming a human quality and competitiveness as well as having good character and high moral. The Indonesian government provides a very large budget to improve the quality of learning. However, in reality, the human resources in Indonesia are still low. This is due to the low quality of education in Indonesia. Data from UNESCO in the Global Education Monitoring (GEM) Report in 2016 show that the quality of education in Indonesia is ranked 10th, while teacher quality is ranked 14th out of 14 developing countries [1]. Hall and Matthews (2008) state that training and aspects of education and knowledge are beneficial for the progress of a nation [2]. Education can improve and develop the quality of education. One of the subjects that plays an important role in education is mathematics because it is considered a basic science that is taught at every level of education. Moreover, mathematics underlies the development of technology which plays an important role in various disciplines and advances human thinking.

There are five competencies in learning mathematics 
[3]: mathematical problem solving, mathematical communication, mathematical reasoning, mathematical connection, and mathematical representation. The combination of these five competencies is called mathematical literacy ability. Mathematical literacy has a mean as an individual's competence to formulate, apply, and interpret mathematics in diverse contexts. It consists of reasoning mathematically and the usage of mathematical concepts, procedures, data and tools to describe, give an explanation for and predict phenomena. These capabilities help individuals to apprehend the function of mathematics in the world and make judgments and decisions [4]. There are seven basic mathematical competencies [5], including communicating, mathematising, representation, reasoning and argument, devising strategies for solving problems, using symbolic, formal and technical language and operations, and using mathematical tools. Mathematical literacy skills help students understand the role of mathematics in daily life. Mathematical literacy skills are related to students' ability to apply mathematical concepts that have been learned into everyday problems better and effectively [6].

According to the Program for International Student Assessment (PISA) data in mathematics in 2018, Indonesian students are ranked 72 out of 78 participating countries and there is no significant difference in the average score with Brazil, Argentina and Saudi Arabia, the score is 379 from OECD average score 500 [7]. In addition the data from PISA, one of the mathematics teachers at SMP Negeri 9 Salatiga stated that the students' literacy skills were still not good. Table 1 is data from the Ministry of Education and Culture shows that the results of the Mathematics National Examination Junior High School in 2019. The data show that the ability of students to solve social arithmetic problems related to problems in daily activity is still not optimal.

Table 1. Percentage of Material Mastery in Mathematics National Examination Junior High School in 2019

\begin{tabular}{cccc}
\hline \multirow{2}{*}{ Indicator } & \multicolumn{3}{c}{ Percentage } \\
\cline { 2 - 4 } & City & Province & National \\
\hline $\begin{array}{c}\text { Solving social arithmetic } \\
\text { problems about banking }\end{array}$ & 69,12 & 46,51 & 41,29 \\
\hline
\end{tabular}

Teachers should be able to choose appropriate learning model or make innovation in learning as an effort to improve the quality of education. Cooperative learning can improve the quality of mathematics learning [8]. In addition, from the results of the questionnaire, it was found that students preferred to have discussions in learning mathematics rather than learning alone [9]. The TAPPS learning model is the development of a cooperative learning model that is highly relevant to the purpose of learning mathematics [10].

Think Aloud Pair Problem Solving (TAPPS) learning is learning that is done in pairs to solve problems. One student acts as a problem solver whose task is to read the questions then solve the problem with think aloud, during the problem solving process the problem solver must always convey what he thinks or does. Other students become listeners who are in charge of assisting the problem solver's thinking process and reminding the problem solver to keep saying what he or she think or do, also in charge of asking clarification if something goes wrong. Listener is not allowed to resolve the problems or give a direct answer [11]. The steps in implementing TAPPS learning are as follows [12].

1. The teacher gives different problems to the problem solver and listener.

2. Think Aloud

3. Problem solver and listener study each problem for 5 minutes.

4. Pair and Problem Solving

a. Problem solver begin to solve the problem and then explain each step of completion to the listener.

b. Listener ask the things that can not be understood, or provide direction and guidance if a problem solver is in trouble.

c. Problem solver and listener switch roles.

5. The teacher observes and assists the discussion.

To optimize the TAPPS learning model, a metaphorical thinking approach can be used. The metaphorical thinking approach is relevant to the purposes of mathematics learning. Learning with a metaphorical thinking approach can improve mathematical literacy skills [13]. The concept of thinking that emphasizes the ability to connect mathematical ideas and existing phenomena, including the meaning of metaphorical thinking [14]. There is a positive response from students towards learning mathematics through a metaphorical thinking approach. The use of metaphorical thinking in the learning process makes learning more meaningful, because students can find a relationship between the concepts being learned and known concepts [15]. Metaphorical thinking concepts based on the structure and way of reasoning are in accordance with the sensory-motory system called conceptual metaphors [16] which includes (1) grounding metaphors are to understand mathematical ideas and relate them to daily experiences, (2) linking metaphors are to establish linkage of these two topics, (3) redefinitional metaphors are to redefine metaphors according to the topic being studied.

In the Minister of Education and Culture Regulation Number 37 of 2018 that in order to meet the basic needs of students in developing their abilities in the digital era, it is necessary to add and integrate informatics content on basic competencies in the basic framework and curriculum structure of 2013 at the primary and secondary education levels. Various studies related to realistic learning using information technology and computers have been carried out. Research from [17] concluded that the use of information technology in learning can improve student achievement including mathematical literacy skills. 
This media helps students keep learning and continue to communicate with their teachers without any limitation time.

Based on the background of the problems described above, the research problem that will be examined in this study is how is the quality of learning in the TAPPS learning model with metaphorical thinking approach assisted by Class Dojo to improve students' mathematical literacy skills? The purpose of this study was to determine the quality of the TAPPS learning model with the Class Dojo assisted metaphorical thinking approach to improve students' mathematical literacy skills.

\section{Materials and Methods}

The research was conducted at SMP Negeri 9 Salatiga in class VII students of the year 2019/2020. This type of research used in this study is a quantitative method. Sampling used simple random sampling technique with class VII B as the experimental class using the TAPPS learning model with metaphorical thinking approach assisted by Class Dojo with class VII C as the control class using the Problem Based Learning model with the scientific approach assisted by Google Classroom. The research design used was a pretest-posttest control group design. In this type of experimental design, there is a random grouping of subjects, there are pretest and posttest. The results of the pretest are said to be good if the values of the two experimental groups are not significantly different. The research design is in the following figure 1 [18].

$$
\begin{array}{llr}
\mathrm{R} & \boldsymbol{O}_{1} & \mathrm{X} \boldsymbol{O}_{2} \\
\mathrm{R} & \boldsymbol{O}_{3} & \boldsymbol{O}_{4}
\end{array}
$$

Figure 1. Pretest-posttest control group design

Which is

$\mathrm{R}$ : The research sample was chosen randomly.

$\mathrm{O}$ : Initial or final test of mathematical literacy skills.

$\mathrm{X}$ : TAPPS learning model with a metaphorical thinking approach assisted by Class Dojo treatment.
The instruments used in this study included learning devices, tests of mathematical literacy skills, student response sheets, and teacher activity observation sheets. Before using the research instrument, it was validated by two validators that were a lecturer and a teacher of mathematics.

Quantitative data analysis consists of three stages according to the stages of learning quality, there were the planning stage, the implementation stage, and the evaluation stage. At the learning planning stage, the learning device validation was carried out, the analysis of the mathematics literacy test results which included the validity, reliability, differentiation and difficulty level of the questions, as well as the validation of the mathematical literacy skills test questions. At the learning implementation stage, data analysis was carried out from the observation of teacher activity and student responses. At the learning evaluation stage, data analysis of the initial test results of mathematical literacy skills was carried out which includes the normality test, homogeneity test and average similarity test to find out that the two sample classes had the same initial conditions. After that, the data analysis of the final test results of mathematical literacy skills was carried out which included the normality test, homogeneity test, individual completeness test, classical completeness test, proportion difference test, average difference test, and average increase difference test.

\section{Results and Discussion}

\subsection{Result}

Based on the results of the learning devices preparation at the learning planning stage, the syllabus obtained an average score of 92.5 in the very good category, the lesson plans obtained an average score of 94.15 in the very good category, the teaching materials obtained an average score of 90.85 in the category very good, student worksheets get an average score of 94.6 in the very good category and the mathematical literacy skills test get an average score of 92.9 in the very good category. The results of the learning devices by the validator can be seen in the graph in figure 2 . 


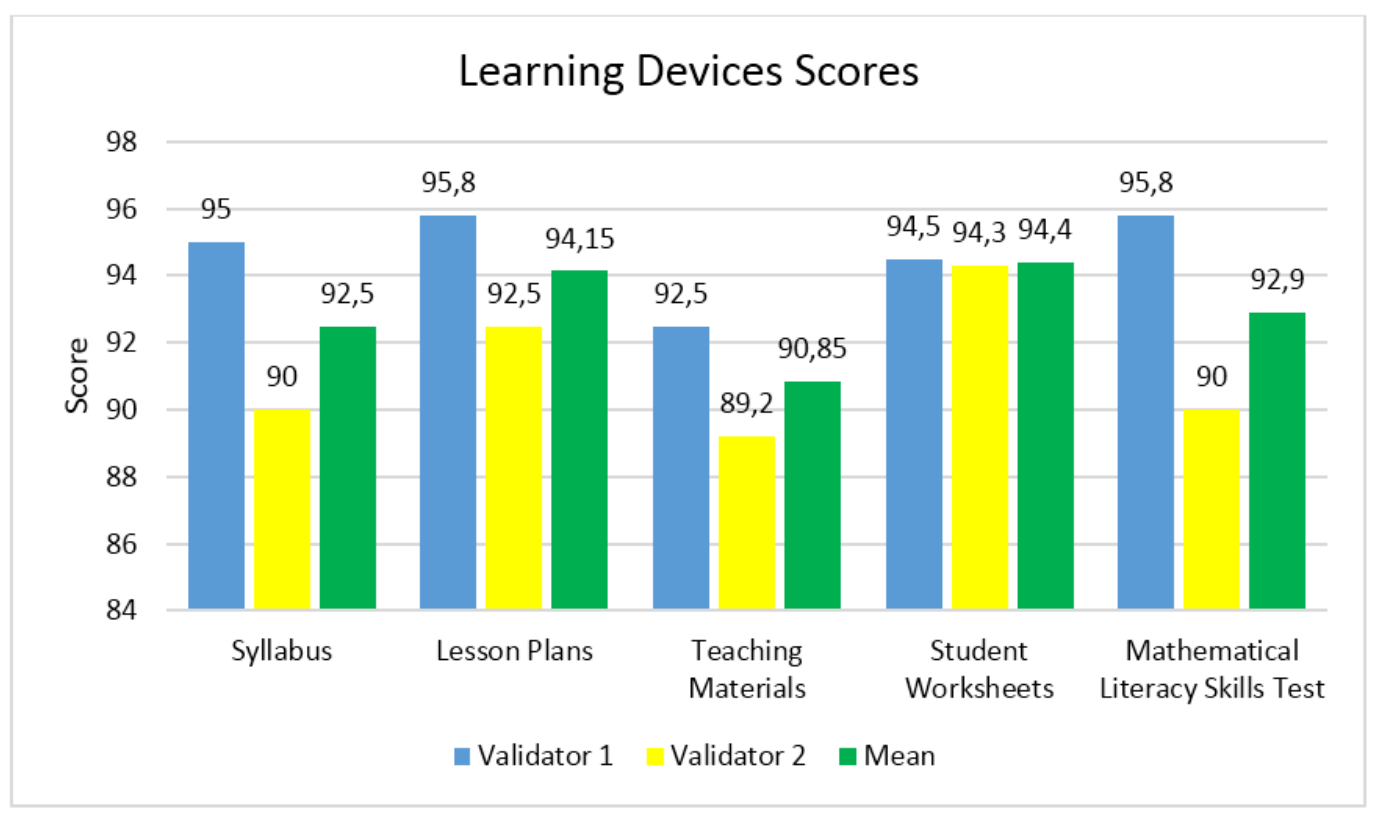

Figure 2. Learning devices scores

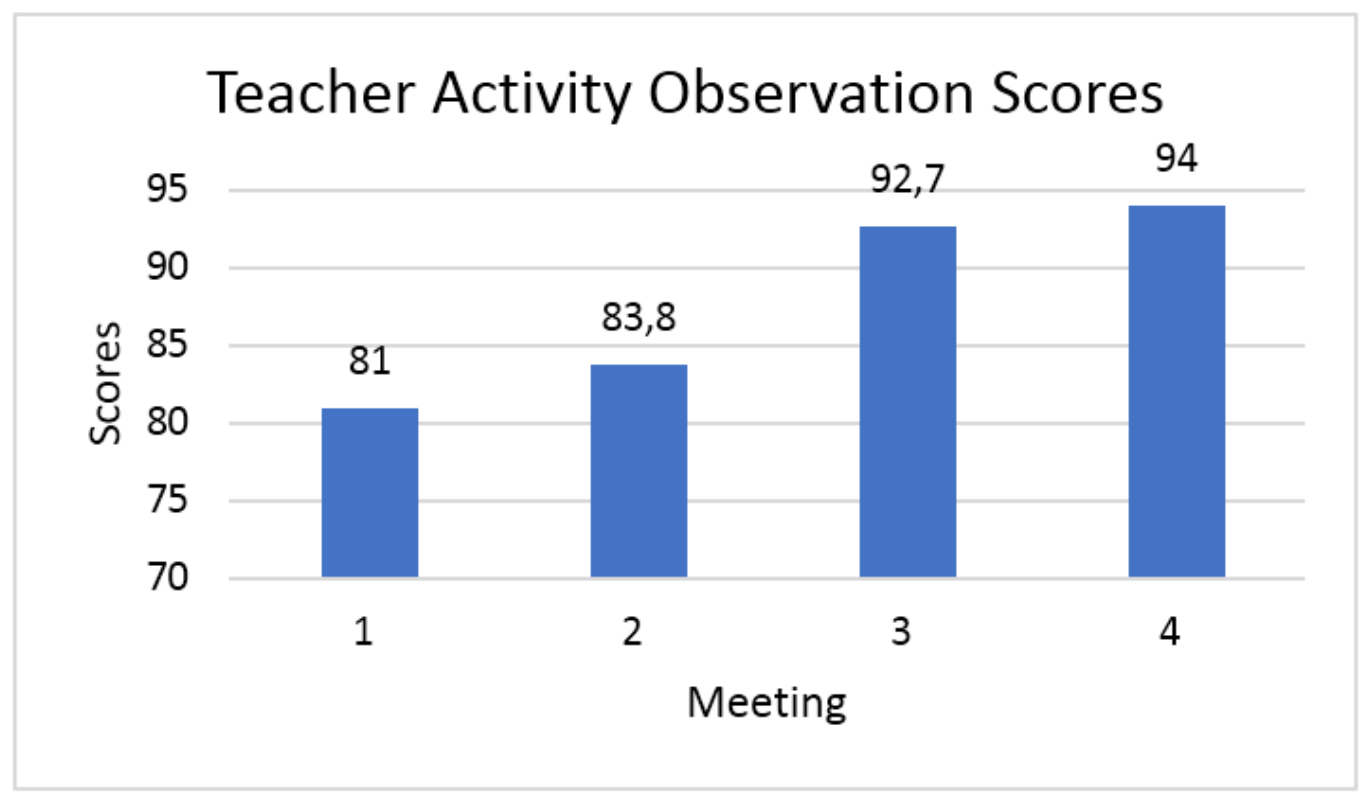

Figure 3. Teacher activity observation scores

During the learning implementation stage, the teacher's activities when teaching are assessed by the mathematics teacher as an observer to determine the learning implementation. Based on the results of the observer's assessment on the teacher activity observation sheet, the score was 81 with a very good category at the first meeting, the score was 83,8 with a very good category at the second meeting, the score was 92,7 with a very good category at the third meeting, and the score was 94 with a very good category at the fourth meeting The results from observing teacher activity at each meeting can be seen in the following graph in figure 3.

Apart from the observation of the teacher activities, the quality of the learning implementation was also assessed from the responses given by students. During learning, students are active and enthusiastic in participating in learning. Students are required to fill out a student response sheet questionnaire which includes student responses to lesson planning and learning process. Based on the questionnaire that was filled in by 30 students, the average score was 84.56 , which means that the responses given by the students were in a very good category.

The results of the students' final test of mathematical literacy skills show the number of students who completed. Students are said to be complete when the student's test score reaches the specified completion limit 
or the minimum completeness criteria. In this study, the minimum completeness criteria used were 53. The proportion of students' classical completeness in the experimental class and the control class can be seen in the following graph in figure 4.

\section{Control Class}

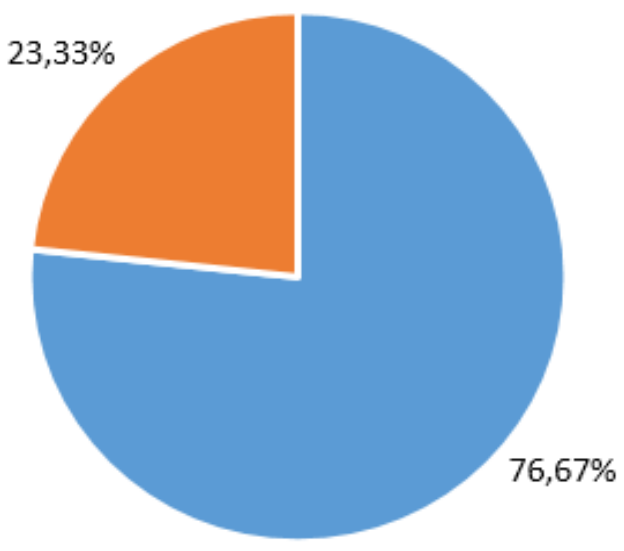

\section{Experimental Class}

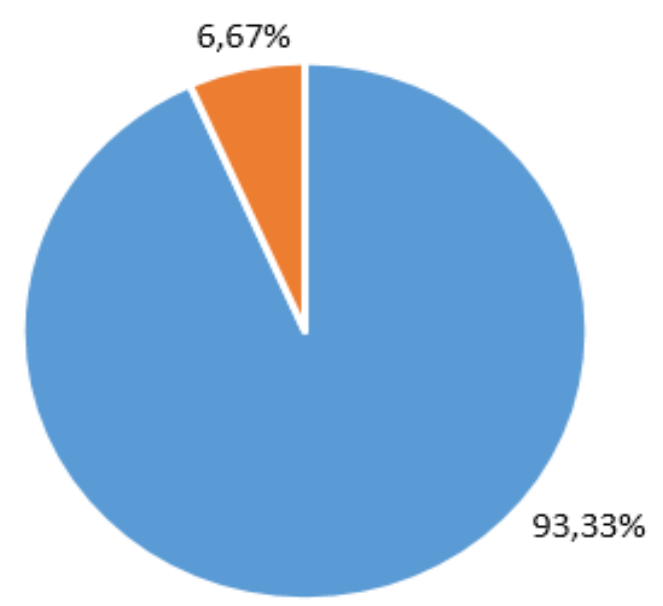

\section{- Completed $\quad$ Not Completed}

Figure 4. The proportion of students' classical completeness

Quantitative data analysis was performed to demonstrate the fulfillment of the research hypothesis. There are five research hypotheses proposed. The first hypothesis test aims to determine students' mathematical literacy skills after participating in TAPPS learning model with metaphorical thinking approach assisted by Class Dojo achieve more than the specified individual minimum completeness criteria (MCC), which is 53. The determination of the hypothesis is as follows.

$\boldsymbol{H}_{\mathbf{0}}: \boldsymbol{\mu} \leq \mathbf{5 3}$ (students' mathematical literacy skills after participating in the TAPPS learning model with metaphorical thinking approach assisted by Class Dojo is less than the same as the specified individual minimum completeness criteria (MCC)
$\boldsymbol{H}_{\mathbf{1}}: \boldsymbol{\mu}>\mathbf{5 3}$ (students' mathematical literacy skills after participating in the TAPPS learning model with metaphorical thinking approach assisted by Class Dojo is more than the specified individual minimum completeness criteria (MCC)

The significant level used in this test is $\alpha=0,05$. The test criteria are to reject $\mathrm{H}_{0}$ if $t_{\text {count }} \geq t_{1-\alpha}$ with $d k=n-1$, accept $\mathrm{H}_{0}$ in other cases. The first hypothesis test results can be seen in the following table 2 .

Table 2. Result of first hypothesis test

\begin{tabular}{ccccc}
\hline $\boldsymbol{t}_{\text {count }}$ & $\boldsymbol{\alpha}$ & $\boldsymbol{t}_{\text {table }}$ & Result & Conclusion \\
\hline 7,702 & 0,05 & 1,699 & $t_{\text {count }}>t_{\text {table }}$ & $\begin{array}{c}\text { The average score of } \\
\text { students } \\
\text { mathematical } \\
\text { literacy skills in the } \\
\text { experimental class is } \\
\end{array}$ \\
& & \begin{tabular}{c} 
more than 53 \\
\hline
\end{tabular}
\end{tabular}

The second hypothesis test aims to determine the proportion of students who complete individually on mathematical literacy skills after participating in TAPPS learning model with metaphorical thinking approach assisted by Class Dojo achieve more than the specified classical minimum completeness criteria, which is $75 \%$. The determination of the hypothesis is as follows.

$\boldsymbol{H}_{\mathbf{0}}: \boldsymbol{\pi} \leq \mathbf{0 , 7 5}$ (the proportion of students who complete individually on mathematical literacy skills after participating in TAPPS learning model with metaphorical thinking approach assisted by Class Dojo is less than the same as the specified classical minimum completeness criteria)

$\boldsymbol{H}_{\mathbf{1}}: \boldsymbol{\pi}>\mathbf{0 , 7 5}$ (the proportion of students who complete individually on mathematical literacy skills after participating in TAPPS learning model with metaphorical thinking approach assisted by Class Dojo is more than the specified classical minimum completeness criteria)

The significant level used in this test is $\alpha=0,05$. The test criteria are to reject $\mathrm{H}_{0}$ if $z_{\text {count }} \geq z_{0,5-\alpha}$, accept $\mathrm{H}_{0}$ in other cases. The second hypothesis test results can be seen in the following table 3 .

Table 3. Result of second hypothesis test

\begin{tabular}{ccccc}
\hline$z_{\text {count }}$ & $\boldsymbol{\alpha}$ & $\boldsymbol{z}_{\text {table }}$ & Result & Conclusion \\
\hline 2,317 & 0,05 & 1,64 & $\begin{array}{l}z_{\text {count }} \\
>z_{\text {table }}\end{array}$ & $\begin{array}{c}\text { the proportion of } \\
\text { students who completed } \\
\text { individually on } \\
\text { mathematical literacy } \\
\text { skills of more than } 75 \%\end{array}$ \\
\hline
\end{tabular}

The third hypothesis test aims to determine the proportion of classical completeness of students 'mathematical literacy in a class using TAPPS learning model with metaphorical thinking approach assisted by Class Dojo achieve more than the proportion of classical completeness of students' mathematical literacy in a class using Problem Based Learning model with scientific approach assisted by Google Classroom. The 
determination of the hypothesis is as follows.

$\boldsymbol{H}_{\mathbf{0}}: \boldsymbol{\pi}_{\mathbf{1}} \leq \boldsymbol{\pi}_{\mathbf{2}}$ (the proportion of classical completeness of students 'mathematical literacy in a class using TAPPS learning model with metaphorical thinking approach assisted by Class Dojo is less than the same as the proportion of classical completeness of students' mathematical literacy in a class using Problem Based Learning model with scientific approach assisted by Google Classroom )

$\boldsymbol{H}_{1}: \boldsymbol{\pi}_{\mathbf{1}}>\boldsymbol{\pi}_{\mathbf{2}}$ (the proportion of classical completeness of students 'mathematical literacy in a class using TAPPS learning model with metaphorical thinking approach assisted by Class Dojo is more than the proportion of classical completeness of students' mathematical literacy in a class using Problem Based Learning model with scientific approach assisted by Google Classroom )

The significant level used in this test is $\alpha=0,05$. The test criteria are to reject $\mathrm{H}_{0}$ if $z_{\text {count }} \geq z_{0,5-\alpha}$, accept $\mathrm{H}_{0}$ in other cases. The third hypothesis test results can be seen in the following table 4.

Table 4. Result of third hypothesis test

\begin{tabular}{ccccc}
\hline$z_{\text {count }}$ & $\boldsymbol{\alpha}$ & $\boldsymbol{z}_{\text {table }}$ & Result & Conclusion \\
\hline 1,79 & 0,05 & 1,64 & $z_{\text {count }}>z_{\text {table }}$ & $\begin{array}{c}\text { The proportion of } \\
\text { classical } \\
\text { completeness in } \\
\text { the experimental } \\
\text { class is more than } \\
\text { the control class }\end{array}$ \\
\hline
\end{tabular}

The fourth hypothesis test aims to determine the average learning outcomes of students' mathematical literacy in TAPPS learning model with metaphorical thinking approach assisted by Class Dojo is more than the average learning outcomes of students' mathematical literacy in Problem Based Learning model with scientific approach assisted by Google Classroom. The determination of the hypothesis is as follows.

$\boldsymbol{H}_{\mathbf{0}}: \boldsymbol{\mu}_{\mathbf{1}} \leq \boldsymbol{\mu}_{\mathbf{2}}$ (the average learning outcomes of students' mathematical literacy in TAPPS learning model with metaphorical thinking approach assisted by Class Dojo is less than the same as the average learning outcomes of students' mathematical literacy in Problem Based Learning model with scientific approach assisted by Google Classroom)

$\boldsymbol{H}_{1}: \boldsymbol{\mu}_{1}>\boldsymbol{\mu}_{2}$ (the average learning outcomes of students' mathematical literacy in TAPPS learning model with metaphorical thinking approach assisted by Class Dojo is more than the average learning outcomes of students' mathematical literacy in Problem Based Learning model with scientific approach assisted by Google Classroom)

The significant level used in this test is $\alpha=0,05$. The test criteria are to accept $\mathrm{H}_{0}$ if $t_{\text {count }}<t_{1-\frac{1}{2} \alpha}$ with $d k=n_{1}+n_{2}-2$, reject $\mathrm{H}_{0}$ in other cases. The fourth hypothesis test results can be seen in the following table 5 .

Table 5. Result of fourth hypothesis test

\begin{tabular}{ccccc}
\hline $\boldsymbol{t}_{\text {count }}$ & $\boldsymbol{\alpha}$ & $\boldsymbol{t}_{\text {table }}$ & Result & Conclusion \\
\hline 2,058 & 0,05 & 2,002 & $t_{\text {count }}>t_{\text {table }}$ & $\begin{array}{c}\text { the average score } \\
\text { of mathematical } \\
\text { literacy skills in } \\
\text { the experimental } \\
\text { class is more than } \\
\text { the control class }\end{array}$ \\
\hline
\end{tabular}

The fifth hypothesis test aims to determine the increase of mathematical literacy skills of students who are taught using TAPPS learning model with metaphorical thinking approach assisted by Class Dojo is more than the increase of mathematical literacy skills of students who are taught using Problem Based Learning model with scientific approach assisted by Google Classroom. The determination of the

hypothesis is as follows.

$\boldsymbol{H}_{\mathbf{0}}: \boldsymbol{\mu}_{\mathbf{1}} \leq \boldsymbol{\mu}_{\mathbf{2}}$ (the increase of mathematical literacy skills of students who are taught using TAPPS learning model with metaphorical thinking approach assisted by Class Dojo is less than the same as the increase of mathematical literacy skills of students who are taught using Problem Based Learning model with scientific approach assisted by Google Classroom)

$\boldsymbol{H}_{\mathbf{1}}: \boldsymbol{\mu}_{\mathbf{1}}>\boldsymbol{\mu}_{\mathbf{2}}$ (the increase of mathematical literacy skills of students who are taught using TAPPS learning model with metaphorical thinking approach assisted by Class Dojo is more than the increase of mathematical literacy skills of students who are taught using Problem Based Learning model with scientific approach assisted by Google Classroom)

The significant level used in this test is $\alpha=0,05$. The test criteria are to accept $\mathrm{H}_{0}$ if $t_{\text {hitung }}<t_{1-\frac{1}{2} \alpha}$ with $d k=n_{1}+n_{2}-2$, reject $\mathrm{H}_{0}$ in other cases. The fifth hypothesis test results can be seen in the following table 6 .

Table 6. Result of fifth hypothesis test

\begin{tabular}{ccccc}
\hline $\boldsymbol{t}_{\text {count }}$ & $\boldsymbol{\alpha}$ & $\boldsymbol{t}_{\text {table }}$ & Result & Conclusion \\
\hline 2,315 & 0,05 & 2,002 & $t_{\text {count }}>t_{\text {table }}$ & $\begin{array}{c}\text { the increase in } \\
\text { mathematical } \\
\text { literacy skills in } \\
\text { the experimental } \\
\text { class is more than } \\
\text { the control class }\end{array}$ \\
\hline
\end{tabular}

The increase in mathematical literacy skills before and after using the TAPPS learning model with metaphorical thinking approach assisted by Class Dojo is calculated using the normalized gain formula (N-Gain). The normalized gain value (N-Gain) in the experimental class is 0.533 . While the normalized gain value (N-Gain) in the control class is 0.334 . 


\subsection{Discussion}

Learning using the TAPPS learning model with metaphorical thinking approach assisted by Class Dojo consists of six steps. The first step is to apply a metaphorical thinking approach to explain the learning material that has been uploaded through the Class Dojo before learning so that students can study the material first. The metaphorical thinking approach includes grounding metaphors, linking metaphors, and redefinitional metaphors. In this study, the chapter used is social arithmetic. The stages in delivering material about profit using the metaphorical thinking approach include the grounding metaphors stage, the teacher delivers the definition of profit and examples in everyday problems. The definition of profit can be seen in figure 5 below.

"If the total selling price or income is more than the original price or capital, the seller makes a profit"

Figure 5. The definition of profit

The capital is the amount spent in buying, operating, or producing something. After that, the teacher gives examples of daily problems related to this definition, these examples can be seen in figure 6 below.

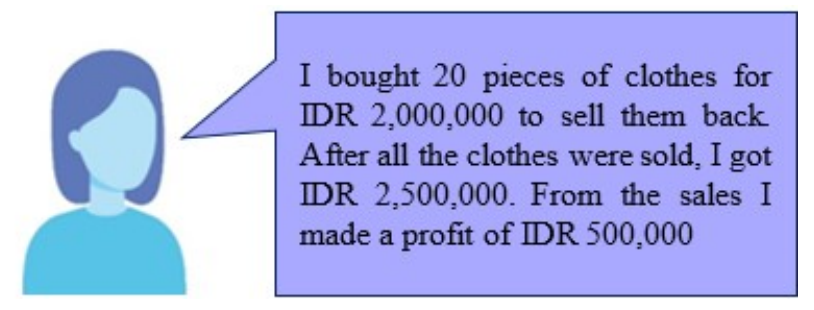

Figure 6. The examples of daily problems related to profit

Profit, if Selling Price $>$ Original Price
Or
Profit, If SP $>$ OP
Profit $=$ Selling Price - Original Price
Or
P $=$ SP - OP

Figure 7. The formula of profit

At the linking metaphors stage, students with teacher guidance look for similarities or relationships between definitions and examples. In the example given, there is the term original price with a value of IDR 2,000,000 and a selling price of IDR 2,500,000, which is similar to the definition of profit that the selling price is more than the original price. The seller got a profit of IDR 500,000, which is equal to IDR 2.500.000 - IDR 2.000.000. From this similarity, it is found that the amount of profit can be calculated by subtracting the selling price from the purchase price. At this stage of redefinitional metaphors, teacher and students define or formulate profits based on the information that has been obtained. The formula determining the profit based on information from the linking metaphors stage can be seen in figure 7 .

The second step of the TAPPS learning model with metaphorical thinking approach assisted by Class Dojo is that the teacher forms groups of two students per group. The third step is for the teacher to give problems to each group which has also been uploaded to the Class Dojo. After that, the fourth step is Think Aloud. Students are given the opportunity to study the problems given for approximately 5 minutes. The fifth step is pairing and problem solving where students are asked to sit according to predetermined groups.

Students carry out their respective assignments, the problem solver conveys the completion steps coherently and the listener listens and corrects when an error occurs. When it is finished, students take turns in roles so that each student gets the same role. In the final step, group representatives present the results of the discussion and reflect together with the teacher regarding the material that has been studied.

In this study, the quality of learning is divided into three stages [19] including the planning stage, the implementation stage, and the evaluation stage. Learning is said to be of quality if at the learning planning stage, the learning devices used are at least in good category as shown by the validation sheet of learning devices including syllabus, lesson plans, teaching materials, and student worksheet. At the learning implementation stage, the learning devices used must be practical so that they are easily accepted by students and the responses from students are at least in good categories and the ability of teachers to carry out learning is at least in good categories as shown by student response sheets and teacher activity observation sheets. Next is the learning evaluation stage which fulfills the effectiveness test of learning outcomes which is assessed based on the completeness of the final test results of the students' mathematical literacy skills.

From the calculation of the validity of the learning device show the learning devices arranged are suitable for use in learning. It can be concluded that the quality of learning planning is categorized as very good. Teacher quality is an important factor in determining student success and one way of improving the quality of education [20]. The aspects assessed by the observer are listed in the teacher activity observation sheet which includes teacher activities when opening lessons, conditioning the class, delivering material, applying the learning model syntax used and teacher activities when closing lessons. Based on the results of the observer's assessment on the teacher activity observation sheet, it was obtained an average score of 87.88 , so it can be concluded that as long as the teacher teaches using the 
TAPPS learning model with metaphorical thinking approach assisted by Class Dojo has a very good category. At the learning implementation stage, an assessment is not only carried out on the teacher but also the responses given by the students. Based on the questionnaire that was filled in by 30 students, the average score was 84.56 , which means that the responses given by the students were in a very good category. It can be concluded that the implementation of learning with the TAPPS learning model with metaphorical thinking approach assisted by Class Dojo has a very good category.

Next is the learning evaluation stage which fulfills the effectiveness test of learning outcomes which is assessed based on the completeness of the final test results of the students' mathematical literacy skills. Based on the data analysis that has been done, it is found that the average mathematical literacy skills of students after participating in the TAPPS learning model with metaphorical thinking approach assisted by Class Dojo can achieve more than the minimum completeness criteria (MCC), which is 53. The average score for the final test of mathematical literacy skills of the experimental class was 75.87 , while the average score for the control class was 66.43.

The proportion of students who complete individually on mathematical literacy skills after participating in TAPPS learning model with metaphorical thinking approach assisted by Class Dojo can achieve more than the specified classical minimum completeness criteria, which is $75 \%$. The percentage of students who achieved completeness in the experimental class was $93.33 \%$. The proportion of classical completeness of students 'mathematical literacy in a class using TAPPS learning model with metaphorical thinking approach assisted by Class Dojo achieve more than the proportion of classical completeness of students' mathematical literacy in a class using Problem Based Learning model with scientific approach assisted by Google Classroom. In the experimental class, there were 28 out of 30 students who completed individually, while the control class had 23 out of 30 students who completed individually.

The average learning outcomes of students' mathematical literacy in TAPPS learning model with metaphorical thinking approach assisted by Class Dojo is more than the average learning outcomes of students' mathematical literacy in Problem Based Learning model with scientific approach assisted by Google Classroom. From the results of the final test of mathematical literacy skills, the average score for the experimental class was 75.87, while the average score for the control class was 66.43. the increase of mathematical literacy skills of students who are taught using TAPPS learning model with metaphorical thinking approach assisted by Class Dojo is more than the increase of mathematical literacy skills of students who are taught using Problem Based Learning model with scientific approach assisted by Google Classroom. The average increase in students' mathematical literacy abilities in the experimental class was 27.53 , while the average increase in the control class was 16.87. The increase in mathematical literacy skills in the experimental class resulted in a normalized gain value (N-Gain) of 0.533. While the normalized gain value (N-Gain) in the control class is 0.334 . So it can be concluded that the average increase in students' mathematical literacy skills in the experimental class and control class is categorized in the moderate level. Even though it has the same category at a moderate level, the normalized gain value in the class using TAPPS learning model with metaphorical thinking approach assisted by Class Dojo is higher than the class using Problem Based Learning model with scientific approach assisted by Google Classroom.

Based on the above discussion, it can be concluded that learning using the TAPPS learning model with metaphorical thinking approach assisted by Class Dojo has a quality in improving students' mathematical literacy skills. The application of this learning model makes students more active and enthusiastic in asking questions, solving problems and expressing opinions during learning. Some research concluded that TAPPS learning model helps students become aware of their thinking processes and improves problem solving skills [11]. TAPPS learning model also makes students better at applying knowledge to formulate strategies and students also show positive perceptions and attitudes during learning. Research by [21] states that in improving students' mathematical literacy skills, an active learning process is needed so that it provides opportunities for students to be able to develop their own ideas. In addition, students also find it easier to understand the material because they use a metaphorical thinking approach that connects learning materials with various problems in daily activity. Students' mathematical literacy abilities get a positive impact from learning with a realistic approach that can be improved by reinventing mathematical concepts [22]. The principle of reinventing the concept of mathematics provides students with the opportunity to discover their own concepts by redefining them based on the relationship between mathematical ideas and everyday problems at the redefinitional metaphors stage. This is in accordance with research by [23] related to the effect of the metaphorical thinking approach on mathematical literacy skills, which concludes that there is a significant effect of student activities after participating in learning on students' mathematical literacy skills. The teacher facilitates students to find concepts through the guidance provided during learning and outside of learning by uploading material before learning through the Class Dojo so that students can study the material first. The research by [24] also states that innovative learning in the 21st century can take advantage of technological advances by integrating technology-based learning media. 


\section{Conclusion}

Based on the description above, it can be concluded that the TAPPS learning model with the Class Dojo assisted metaphorical thinking approach has a quality and can improve mathematical literacy skills. This is indicated by the learning devices that have been arranged at the learning planning stage which are categorized as very good. At the learning implementation stage, based on observations of the implementation of learning by the observer on teacher activities during teaching and the results of student response questionnaires, it can be concluded that teacher activities and responses given by students are in very good categories. At the learning evaluation stage, the mathematical literacy abilities of students in the experimental class can achieve more than the individual and classical minimum completeness criteria (CMCC), the proportion of classical completeness of students' mathematical literacy abilities in the experimental class is higher than the control class, the average mathematics literacy learning outcomes in the experimental class are better than the control class, and the increase in mathematical literacy skills in the experimental class is more than the control class.

\section{Acknowledgement}

Sources of funding for this research, DIPA Universitas Negeri Semarang with the contract no: SP DIPA-023.17.2.677507/2020 date December 27, 2019 in accordance with The Research Implementation Assignment Agreement Letter DANA DIPA UNNES no: 108.23.4/UN37/PPK.3.1/2020 date April 23, 2020 and in accordance with The Agreement Letter of Community Service no: 23.28.5/UN37/PPK.4.4/2020 date May 28, 2020. SMP Negeri 9 Salatiga has facilitated the data collection process so that this research can be conducted.

\section{REFERENCES}

[1] Utami, S, “Meningkatkan Mutu Pendidikan Indonesia melalui Peningkatan Kualitas Personal, Profesional, dan Strategi Rekrutmen Guru”, Prosiding Seminar Nasional Pendidikan FKIP, vol. 2, no. 1, pp. 518 - 527, 2019.

[2] Wardono, W., \& Kurniasih, A. W, "Peningkatan Literasi Matematika Mahasiswa Melalui Pembelajaran Inovatif Realistik E-Learning Edmodo Bermuatan Karakter Cerdas Kreatif Mandiri”, Kreano, Jurnal Matematika Kreatif-Inovatif, vol. 6, no. 1, pp. 95 - 102, 2015.

[3] National Council of Teacher Mathematics. Principles and Standards for Schools Mathematics. Res-ton. VA: NCTM. 2000.

[4] OECD, PISA 2015 Results (Volume I): Excellence and Equity In Education. PISA. Paris: OECD publishing, 2016.
[5] OECD, PISA 2015 Assessment and Analytical Framework: Science, Reading, Mathematic, Financial Literacy and Collaborative Problem Solving, revised edition. PISA. Paris: OECD Publishing, 2017.

[6] Sari, R. H. N, "Literasi Matematika: Apa, Mengapa dan Bagaimana?”, SEMINAR NASIONAL MATEMATIKA DAN PENDIDIKAN MATEMATIKA UNY 2015, pp. 713 - 720, 2015.

[7] OECD, PISA 2018 Result (Volume I): What Students Know and Can Do. PISA. Paris: OECD Publishing, 2019.

[8] Abdullah, N. S., Mulbar, U., \& Minggi, I, “The Quality Improvement of Matematics Learning Through the Implementation of Cooperative Learning Model with Scientific Approach to Class VI/A Students at SD Inpres Kassi Makasar”. Jurnal Daya Matematis, vol. 5, no. 1, pp. 1 - 13, 2017.

[9] Irham, M., \& Zainuri, "Efektivitas Pembelajaran Think Aloud Pair Problem Solving Ditinjau dari Kemampuan Pemecahan Masalah". Unnes Journal of Mathematics Education Research, vol. 5, no. 1, pp. 60 - 70, 2016.

[10] Buchori, A., Rahmawati, N. D., \& Baedowi, S, "Pengembangan Mobile Learning dengan Model TAPPS pada Materi Barisan dan Deret Kelas X Semester I di SMA Nasima Semarang”, Media Penelitian Pendidikan: Jurnal Penelitian dalam Bidang Pendidikan dan Pengajaran, vol. 9 (2 DESEMBER), 2016.

[11] Kani, N. H. A., \& Shahrill, M, “Applying The Thinking Aloud Pair Problem Solving Strategy in Mathematics Lessons”, Asian Journal of Management Sciences and Education, vol. 4, no. 2, pp. 20 - 28, 2015.

[12] Winarti, E. R., Haryanti, M. D., \& Asih, T. S. N. 2019. Student's problem solving ability in thinking aloud pair prolem solving learning assisted by schoology viewed from mathematical disposition. Unnes Journal of Mathematics Education, 8(1): 14 - 18 .

[13] Setiani, C., Waluya, S. B., \& Wardono., "Analysis of Mathematical Literacy Ability Based on Self-Efficacy in Model Elicting Activities Using Metaphorical Thinking Approach”. Journal of Physics: Conference Series, 2018. doi :10.1088/1742-6596/983/1/012139.

[14] Carreira, S, “Where There’s a Model, There’s a Metaphor: Metaphorical thinking in Student's Understanding of a Mathematical Model”, An International Journal Mathematical Thinking and Learning, vol. 3, no.4, pp. 261 287, 2001.

[15] Afrilianto, M.., "Peningkatan Pemahaman Konsep dan Kompetensi Strategis Matematis Siswa SMP dengan Pendekatan Metaphorical thinking”. Infinity Journal, vol. 1, no. 2, pp. 192 - 202, 2012

[16] Hendriana, H., 'Pembelajaran Matematika Humanis dengan Metaphorical Thinking untuk Meningkatkan Kepercayaan Diri Siswa”. Infinity, vol. 1, no. 1, pp. 90 - 103, 2012.

[17] Maulana, D. F., Wardono, Marwoto, P., \& Mariani, S., “The Ability of Mathematical Literacy on Learning Treffinger Realistic Assistance Schoology", Journal of Physics: Conference Series, 2019.doi:10.1088/1742-6596/1321/3/03 2132. 
[18] Sugiyono. Metode Penelitian Pendidikan Pendekatan Kuantitatif, Kualitatif, dan R\&D. Bandung: Alfabeta, 2018.

[19] Wicaksana, Y., Wardono, W., \& Ridlo, S, “Analisis Kemampuan Literasi Matematika dan Karakter Rasa Ingin Tahu Siswa pada Pembelajaran Berbasis Proyek Berbantuan Schoology". Unnes Journal of Mathematics Education Research, vol. 6, no. 2, pp. 167 - 174, 2017.

[20] Purwoko, R. Y, "Urgensi Pedagogical Content Knowledge Dalam Meningkatkan Kualitas Pembelajaran Matematika", Jurnal Pendidikan Surya Edukasi (JPSE), vol.3 no. 2, pp. 42 $-55,2017$

[21] Wardono, \& Mariani, S. "The analysis of mathematics literacy on PMRI learning with media schoology of junior high school students". Journal of Physics: Conference
Series, 2018. doi:10.1088/1742-6596/983/1/012107.

[22] Machromah, I. U., Sutama, Prayitno, H. J., Faiziyah, N., \& Fatmasari, L. W. S. "Designing PISA-like Mathematics Task to Assess Students' Mathematical Literacy”. Universal Journal of Educational Research, 8(10): 4986 - 4995. doi: 10.13189/ujer.2020.081072.

[23] Wahyuni, I., Noto, M. S., \& Hikmah, A. N., "Pengaruh Pendekatan Metaphorical Thinking Terhadap Kemampuan Literasi Matematis Siswa”. Euclid, vol. 3, no. 1, pp. 491 501, 2017.

[24] Afiyanti, I., Wardono, W., \& Kartono, K, "Pengembangan Literasi Matematika Mengacu PISA Melalui Pembelajaran Abad Ke-21 Berbasis Teknologi”, PRISMA, Prosiding Seminar Nasional Matematika, vol. 1: 608 - 617 